\title{
Post COVID-19: New Era for Higher Education Systems
}

\author{
Mustafa Kayyali \\ Azteca University, Mexico, North America \\ Corresponding author: kayyali@heranking.com
}

Received: 19 Sept., 2020

Revised: 13 Nov., 2020

Accepted: 02 Dec., 2020

\begin{abstract}
On November 17, 2019, according to several sources, the first case of COVID-19 appeared in Wuhan, China, for a 55-year-old man. In addition to that, evolutionary estimates in genetic studies conducted in the early months of 2020 indicated that the Severe Acute Respiratory Syndrome (SARS) Virus most likely transfered to humans in the period between October $6^{\text {th }}, 2019$ and December $11^{\text {th }}, 2019$. The reason that led to the rapid spread of this epidemic is that its symptoms may not appear on the infected person in which, symptoms of the disease might not be shown before two weeks of the infection. The World Health Organization WHO recognized the spread of COVID-19 as a pandemic on March $11^{\text {th }}, 2020$. In the first period of the virus's spread, specifically in January and February of 2020, Italy, Iran, South Korea, Japan, and China reported increasing numbers of cases. Later that month, specifically on the $26^{\text {th }}$ of February, the number of cases outside China rapidly exceeded the number of cases inside China, with the total number of cases reaching 2,790 distributed in 37 countries. During the next few days, the virus spread around the world at a steady speed, and there was no way or method to find a solution or treatment for its spread. COVID-19 had devastating effects on all living areas and on all industries, in which, it had shocking effects and frightening figures related to the movement of the global economy and companies in a manner related to the repetition and duration of closures in addition to effects beyond description related to current and future effects in connection with the methodology of higher education, universities, and educational institutions, and the related future repercussions. COVID-19 causes many symptoms such as fever, dry cough, fatigue, headache, loss of the sense of smell and taste, it also causes difficulty breathing and nasal congestion. COVID-19 is an abbreviation for coronavirus disease of 2019. Throught out this paper, The virus is mentioned as Coronavirus, COVID, and COVID-19.
\end{abstract}

Keywords: Higher education - universities - higher education institutions -accreditation - future Coronavirus-COVID-19 - the future of higher education.

In the past months, many studies related to the effect of COVID-19 on higher education institutions and operation were published and many seminers and meetings were addressing the virus [22]. This study How to cite this article: Kayyali, M. (2020). Post COVID-19: New Era for Higher Education Systems. IJASE., 8(02): 117-131. 
may not create new ideas or present new prospects, but rather; aims to provide general and comprehensive clarification and proposed solutions to overcome this crisis facing humanity, and mitigate its effects. This research also focuses on a very important point, which is that even if a cure and drug are found for COVID-19, humanity could be exposed in the coming years to more deadly, destructive, and impactful epidemics than COVID-19, and it must then wait for many years before the appropriate treatment appears. This research assumes the possibility of benefiting from solutions and ideas resulting from COVID-19 in the event that another similar epidemic emerges in the coming years. The author of this research does not indicate or hint at the emergence of other epidemics in the coming years, but rather indicates the possibility of their emergence taking into account all the data related the emergence of Corona. The study provides an explanation of the effects of Corona on the structure of international higher education systems and quality assurance bodies, its impact, the mechanism of dealing with the virus, and some steps that can be taken to mitigate the possible impact.

A number of researchers and independent sources have indicated that more than 147 million people have lost their jobs around the world due to the spread of the COVID-19 [1], which caused workers to lose an estimated \$ 3.5 trillion in the wage mass, according to Guy Ryder, Director-General of the International Labor Organization ILO [51]. The level of global consumption decreased by 4.2 percent, equivalent to $\$ 3.8$ trillion, which is equivalent to the GDP of a country such as Germany or Spain, and these financial repercussions mentioned above, in their combined cost, exceed the costs of the wars of the United States of America in each of the wars of Vietnam, Iraq, Afghanistan or the Gulf War [30][43].

Despite the very damaging effects of COVID-19 on the sector of Higher Education, the virus led to great progress of a lot of medical and scientific research related to immunity, prevention, and protection, and it has also contributed to the development of studies related to viruses, their internal structure and the method of transmission of infection. In addition, it contributed to the emergence of many types of research related to the development of human immunity and the reasons that prompted the virus to infect old people without infecting children.

Humanity has always been able to overcome the plagues it encountered and managed to survive, continue, recover, and start over and over again. Throughout history, the world has witnessed many deadly diseases and epidemics [41] some of them were epidemics confined to specific countries or geographical areas and some were global epidemics. Those epidemics claimed the lives of tens or even hundreds of millions of people [21] and caused demographic, social, and economic changes in the whole world. Pandemics changed the course of history, such as the plague that spread in the thirteen and fourteenth centuries [39], the plague of London, which appeared in 1665 [47], and caused the death of a quarter of the city's population, and smallpox, which appeared in the fifteenth century in the North and South American continents, the cholera epidemic that appeared in the nineteenth and twentieth centuries [27] that caused the death of millions, and yellow fever that appeared in the late nineteenth century [17]. The Spanish flu that appeared in 1918 [46] and also caused the death of millions, Avian influenza appeared in 2004 [25] and swine flu appeared in 2009 [52].

The history of mankind does not seem pure from epidemics and diseases, as it seems as if humanity has been for long ages in a state of war with an invisible enemy, and its fortresses or headquarters cannot be attacked or surprised or prepared for a specific war. This enemy is considered one of the most dangerous enemies at all because it attacks people without a prior warning. 


\section{Objective of the Research}

This research aims to provide a brief overview of the impact of COVID-19 on the higher education sector, HEIs and higher education institutions, and the challenges that universities and accreditation assurances agencies are facing, and the measures those instititions are preparing in order to stand against this devastating epidemic that has had deadly and devastating effects in all fields, businesses and industries. The research also aims to provide a ray of hope and a candle of light to illuminate the way for all parties and stakeholders related, connected and active in the international higher education system. The research tries to present some suggestions, advice and recommendations that can serve decision-makers in the field of higher education.

\section{Economic consequences of Covid-19}

The outbreak of the epidemic caused global economic losses estimated at 50 billion USD in February 2020 alone [13]. Some studies indicate that the tourism sector alone is exposed to losses estimated at about $\$$ 1.2 trillion, and the United Nations Conference on Trade and Development (UNCTAD) estimates that for every $\$ 1$ million lost in international tourism receipts, a country's national income could decrease by up to $\$ 3$ million. The matter has catastrophic effects on the employment and business sector [16]. The whole world stands in a state of fear and anxiety about the pandemic that has swept all the countries of the world and caused the world to change within the past year as if it is at a crossroads between reaching the oasis of safety or the inevitable fallout that cannot be tolerated. All researchers around the world silently watch the evolution of this virus, which appeared as we mentioned in the introduction in China, a strongly rising economic and geopolitical power that has caused heavy losses exceeding billions of dollars.

As a result of this deadly virus, all international economic development processes have stopped, international trade rates have decreased, and industries related to alternative energy have decreased as a result of the stopping of the international economy to the extent that has pushed the manufacturers of solar energy and hybrid energy systems to reduce their activity and the level of their manufacture. In addition, the virus has caused devastating consequences on the sectors of tourism, industry, energy, air transport, paper publishing sectors, book fairs, translation, and scientific research sectors, as book fairs have stopped in all countries of the world [7]. All literary and scientific seminars and meetings, all art exhibitions, poetry and artistic evenings, and theatrical performances were stopped [8], which caused great losses to these intellectual and knowledge sectors.

The pandemic has caused a painful blow to the global economy, and although the full extent of the human and economic impacts of the pandemic will not be clear for months or even years, the losses in these two areas will be great, exceeding the financial limits and reaching the knowledge and heritage of humanity as a whole. The spread of the virus in this regard could lead to political unrest in many countries that suffer mainly from financial difficulties or those countries that suffer from high levels of unemployment, which will contribute to the increase in the rates and spread of bureaucratic, dictatorial, and anti-democratic procedures. The pandemic could also contribute to the occurrence of chaos, clashes, and civil wars in those countries, and this, in turn, reduces the ability and effectiveness of countries in helping companies and the private sector at a time when these companies are in dire need of help.

In the short term, some emerging market economies and developing countries (East Asia, the Arab region, and Africa) will be the most affected economically, taking into consideration the weakness and 
fragility of their health, scientific, intellectual, and educational systems. Whereas, third world countries and countries that are unable to grow during the first decade of the twenty-first century will be the direct victims of the consequences of the virus on developing and developed countries. Other countries that depend entirely on trade, tourism, or expatriate remittances from abroad, or depend on exports of raw materials or the export of valuable materials, or that mainly suffer from difficulties in financial liquidity will suffer a frightening economic recession with a devastating effect that will take a very long time for them to recover from the impacts of the virus and the burden of debts. When looking at other countries that previously suffer from debts owed to the International Monetary Fund, or those countries that have suffered from wars and conflicts (third world countries and the Arab region), we will find that the effects of the virus will be deadly so that, it will increase their financial and economic crises and lead to the financial collapse in a way similar to the economic collapse in countries such as Venezuela, and Zimbabwe [55].

As a result of this chaos, and as a result of the state of international economic fluctuation, cryptocurrency prices rose in a way that they had not reached for more than 3 years, due to the instability of the prices of dollar and gold in addition to people's desire to stabilize their revenues in a way in which they could preserve their value. The repercussions will have a severe impact on the countries that are based on the export of oil derivatives, phosphates, gas, and diesel, and the reason for this is the low rates of consumption, manufacturing, and quarantine cases that are carried out by developed countries. Also, the cost of extracting, processing, transporting, and storing petroleum materials caused the rise of this problem to the point in which, the price of a barrel of oil fell below $\$ 0$ per barrel of crude oil. This was caused by an excess of supply and a significant drop in demand due to the Corona pandemic, which is the first time that a barrel of oil has decreased to this level. If there is a sign of this action, then this means that the virus is a worrying sign of an unprecedented global energy glut, as the Coronavirus pandemic has stopped travel and curbed economic activity [54].

\section{Direct Consequences of COVID-19}

A third of the world's population faces some form of movement restriction due to the coronavirus pandemic [2]. As a result of the continuation of this crisis, many basic questions have surfaced, the most important of which is: When will life return to normal [29]? Will life return to normal [4]? What kind of economic repercussions can we expect as a result of this global epidemic[54]? Can we expect a new world order based on the new reality imposed by the virus [44]?

The spread of the virus caused a decrease in consumer spending around the world, as travel and the tourism sector in general stopped, and the industry slowed due to restrictions imposed on movement and restrictions imposed on industrial movement as a whole and Lower consumption has lowered demand [36]. Unemployment figures in the United States of America and other key indicators indicate that the impact of the current crisis was more severe than the impact of the global financial recession in 2008 [10]. Since the imposition of quarantine measures in the United States, about 22 million people have lost their jobs as a result of these very harsh measures.

Everyone agrees that the impact of the economic impact will be severe and palpable in the short term [34]. However, the most controversial question that economists ask is: What will happen to the global economy in the medium to long term [19]? Will we go through a recession followed by a sudden rebound once the virus is contained, as many expect? Or will we see a recovery at a slower pace? will the COVID-19 effect be permanent, which prompts us to adapt to it? if new waves of the virus occur during the coming 
period, specifically with the advent of winter, what is the ability of global economies to withstand these devastating consequences? Will this lead to a global financial and economic downturn in 2021, which will lead to a complete halt in demand and in turn lead to international economic collapses, with their effects surpassing the recessions that occurred in 1908, the recession that followed World War I, and the financial collapse of 2008 ?

When we talk about Corona's losses, of course, the direct loss relates to the national income of countries and the loss of travel, airline, and transportation companies, which is a material loss whose value exceeds billions of dollars and the loss of thousands of their jobs. The long-term impact is the moral, scientific, and psychological loss of countries that have suffered from the spread of the virus. Imagine the total amount of time that humanity has paid during the past months? Imagine the millions of years in total hundreds of millions of people spent in their homes during quarantine periods? How much is the total loss of humanity during these days? The present seems mysterious to many people, students and researchers.

\section{COVID-19 Impact on Higher Education}

The Coronavirus crisis and the resulting closures affected almost every sector of the global economy, and these crises have caused some sectors to turn upside down. Perhaps one of the most directly affected by this process is the higher education sector. The outbreak of the Coronavirus epidemic has led to a major educational crisis due to the closure of schools and universities around the world and the disruption of formal education services, as more than 290 million students around the world have been directly affected [5]. Many countries have decided to close schools, colleges, universities, and all educational institutions to reduce affection rates. Here, the basic dilemma arises in the need for governments to choose between two options: either closing educational institutions, preserving lives, and limiting direct contact, or keeping them open to mitigate the devastating economic, scientific and cognitive effects resulting from their closure. It is not easy for all members and stakeholders in educational institutions to make such a decision or even transfer education to the distance education system, as it is not easy for families and students to accept that the educational process takes place entirely from home, so it is very difficult for parents and students to accept this direct transfer in the method of delivery for the education system [40].

This transformation caused a shock to the social life of children and their families. The most severe of all is the system of general examinations and the student evaluation system at the end of each semester. Will these assessments be reliable? Will it be an acceptable alternative to the traditional system? will it be a bad choice, totally unacceptable? Even more importantly, will the degree of the student who studied a complete educational program online considered acceptable? As for the labor market, will employers treat both graduates (the first graduated from an in-person program and the second from an online program) the same treatment? Due to the situation of uncertainty, we find that the questions asked to go far beyond the answers that can be provided to these questions, among them, will the student accept paying $\$ 73,000$ to study the MBA program in the distance education system which is the same cost for the in-person program cost? Students believe that just as an e-book is about four times cheaper than a paper book, the same applies to distance education, as it should be less expensive than in-person education [33].

The most urgent question in this regard is, in the event that the prestigious universities switch to the distance education system, will they still have the distinction they had before? What will distinguish these universities when they implement the distance education system from other universities around the world? Will the ranking standards for universities around the world still carry the same previous standards 
in the event that universities switch to distance education? In the coming years, we may witness a radical change in the structure and systems of higher education institutions around the world.

Coronavirus also caused unprecedented shocks in the higher education system, and more clearly, not all students, not even universities, teaching and administrative bodies, were able to change and move to this completely new system, and the students' societies did not accept this change too. It is hard to request from physics professors to prepare lectures and equations using the Zoom program because this method is completely brand new to them. It is also difficult for all students to accept this shift in which, they are requested to attend a full program of study, lectures, and register attendance while they are in front of a laptop or mobile screen. This topic needs studies in behavioral psychology and restrict student distraction as much as possible. An example of this is what will the student do during a physics lecture that he attends on the Zoom program on his mobile device if his girlfriend sends him a message? What will the professor presenting this lecture do in the event of a technical error on the laptop or in the communication program? These problems are an integral part of a complex behavioral and social system that all parties to the educational process must be prepared to accept and understand.

All members and stakeholders of the educational process must be informed that we are facing an international dilemma and a catastrophic epidemic, and we must all try to participate in accepting intermediate solutions to overcome these difficulties. In this regard, we are not proposing that what is happening is not problematic, or that dealing with this new system is very simple, as this educational system represents a new challenge for all parties. We are almost certain that educational institutions are not at all happy with this new educational system. What calms us is that we cannot do anything to change this new reality. Universities must encourage and support the teaching staff to overcome the psychological, emotional, and physical difficulties of the virus among students [26]because for those students, the future is vague, unclear, ominous, and uncertain, and there are no good predictions at all, as these students will enter the labor market that has been almost halted and stopped mainly due to the virus.

\section{Academic Impact of COVID-19}

Perhaps the direct financial impact of the losses of universities is represented in the potential income losses of foreign students who returned to their homelands after the brute application of the distance education system, and they were able to continue studying from their countries as these students provided a large and increasing share of the total income due to the high fees they pay and the increase in their numbers during the previous years. In addition, the revenues of these students help universities to finance research and studies conducted by the university. Taking into account this new reality, these universities will not be able to provide the required money that contributes to financing researches. In Britain, for example, there are more than 13 universities at risk of bankruptcy without the possibility of supporting them [9]. In addition, with the application of this new educational system, higher education institutions must provide an additional educational and scientific value that distinguishes them from other universities, and this will lead to new and severe pressures on higher education institutions that mainly suffer from the financial difficulties resulting from the virus. The new reality has also caused a difficult and suffocating negative impact on universities and educational institutions. It is well known that universities rent a number of buildings, playgrounds, swimming pools, public services centers, and car park subscriptions allowance for their students and faculty staff, and these leased properties are considered a major tributary of the tributaries that educational institutions depend on to cover their expenses. This led to educational 
institutions incurring astronomical sums that were paid in advance and were not utilized at all, which caused the fiscal deficit, in addition to the financial deficit caused by students' reluctance to register at the university due to the blurry conditions caused by the epidemic.

It is also important to note that the consequences of coronavirus were not limited to losing financial returns from previously rented properties. In addition, it can be noted that the old and ancient universities need to conduct periodic maintenance for their buildings, such as colleges, institutes, and research centers [31][28]. This may seem at no cost to new universities, and those universities and HEIs established after 1975 but it might have a very large impact for universities built before 1800 such as Harvard, Oxford, and Yale in particular, and this is clearly evident in the Ivy League universities Which includes (Brown University, Columbia University, Cornell University, Dorsmith College, Harvard University, University of Pennsylvania, Princeton University, and Yale University) [53].

In addition, one of the most prominent changes that universities will face is the decline in fiscal revenues, which must act dynamically to avoid its negative effects. To clarify more, it should be noted that the number of international students in some universities exceeds $30 \%$ of the total number of students. Accordingly, what will happen to these universities when these international students return to their home countries? Certainly, this will lead to the collapse of universities' revenues and change their future plans. This will also force universities to reduce expenses, dispense with the contracts of some of its contractors, and increase registration fees for its students to cover the financial deficit. All of those factors will worsen the situation and will contribute only to the acceleration of the collapse. Suspension of the registration of international students will not only have an impact on universities alone, but will also have an impact on the sums of hard currencies that these students pay to the state treasury for housing, transportation, restaurants, hotels, swimming pools, and canteens, and all the financial costs they pay for the services they receive, which in turn, will contribute in supplying the state treasury with large sums of money.

In 2017, the amount that international students pump into the British economy was estimated at around 25 billion pounds [23]. In normal cases, universities can take advantage of internal loans from the government, but taking into account the internal financial collapse in many countries as a result of repeated closures and stoppages of industry, commerce, and tourism, this will lead us to believe that higher education institutions (and these universities) will be the biggest loser in these difficult circumstances. Higher education cannot be portrayed as a luxury that can be dispensed with. Education is our weapon to defeat Coronavirus, and if we stop education, how will we be able to confront the epidemic?

High-income private universities are expected to lose hundreds of millions of dollars in the next fiscal year, including Johns Hopkins University in The USA. As for the British universities, they will collectively face a significant financial decline, estimated at least $\$ 3$ billion, next year due to an expected decrease in the number of students enrolled in universities, according to the British Institute for Economic Consulting in London [37]. As for Australia, its universities will lose nearly 21,000 jobs, including 7,000 jobs in the field of scientific research in universities [49]. The most frightening possibility for universities that cannot find a resource to cover their financial deficit is the complete closure of these universities, while other universities will be more fortunate if they can be merged with other universities [35]. How do we envision the state of merging universities with each other and what are the legal consequences of these new universities? These new universities will have to start from scratch in terms of their programs, management, and quality systems. Taking all the previous criteria into account, and with regard to the financial side of higher education institutions, Coronavirus can be viewed as a black hole that absorbs 
hundreds of millions of dollars from the budget of higher education institutions and its existential impact might reach the university legal status, its existence, and personal operation. Deficit reaches 2.6 billion $£$ in Britain for the academic year 2020-2021 [48].

\section{Online Teaching: The Best Available Option}

Many studies have elaborated on and clarified this point, and therefore we will not talk about it in detail. Distance learning is one of the sectors that has flourished during the past years, specifically in the early 2010s, as many universities and well-established educational institutions have begun to provide their educational programs through the distance study mode, as well as many quality assurance bodies, specialized in the accreditation of distance learning programs and even, Traditional quality assurance institutions have recognized these programs that were delivered via online mode. What is important in this regard is that the educational programs that were taught in these institutions were theoretical educational programs that do not require in-person interaction with the lecturer, nor do they require any practical practice such as languages, management, business administration, literature, and journalism while the implementation of this educational system seems impossible in the study of medicine, scientific faculties, mathematics, physics, and similar educational fields. Ludger Wößmann, a German professor of economics at the University of Munich and director of the Ifo Center for Economic Research (Leibniz Institute for Economic Research at the University of Munich), declared that online education was not a good alternative to traditional education. He added saying that It is necessary we do everything applicable to return to traditional education as soon as possible while taking the necessary preventive measures, and if this is not possible, a complete schedule for online education must be established [32]. Even when we talk about distance education, it does not seem completely fair to all countries of the world. On the one hand, and when looking at the countries of the developed world, we find that more than $95 \%$ of their regions are equipped with the Internet and fast connection while it seems tragic in other regions and countries such as India, where about $70 \%$ of Indians living in rural areas still do not have access to digital technology [24], which makes the return of traditional education a critical issue in these areas, according to him.

With the similar mechanism and methodology of education in all universities by dealing with specific programs for teaching such as Zoom, Skype, and programs for each university, it seems that the differences between universities are diminishing and there is no longer that big difference between small universities and those advanced universities or universities with high ranking and those with a lower ranking. Universities have also begun to encourage the transition to this new educational system and direct communication with students through Telegram and WhatsApp groups and to encourage the teaching staff to share all educational resources books, and educational notes with students. Experts believe that the impact of the current COVID-19 during the years 2020 and 2021 will change the structure of higher education at the international level, and that education will be different in quantity and quality during the coming years [3].

\section{COVID-19 Impact on Labour Market for HEIs}

The controversial issue of the impact of COVID-19 on the labor market sector appears for graduates of universities and higher education institutions. The direct problem in this case for practical college students is that these students were unable to follow the practical application of theoretical skills in the 
best possible way, and the economic impact that hit the economies of developing countries caused the suspension of tens of thousands of jobs and professions in addition to the suspension of trade and large companies. Regarding working online, or using the internet as a medium for work, we find that the gigantic companies (especially technology companies) monopolize most of the work and jobs, which will increase the difficulties and burdens placed on governments and countries. It is also known that five American technology companies (Google, Amazon, Facebook, Microsoft, and Uber) have liquidity exceeding \$ 504 billion, which amounts to $30 \%$ of US liquidity [6]. It is possible to transfer some works and convert its work system to include work via the Internet, but this matter does not include all works and all jobs. The direct dilemma at this point is that students in the current period are thinking about studying educational programs that do not include the direct application of practical skills, which will lead to universities focusing on some departments and neglecting other educational departments and programs. Some can suggest that the COVID-19 epidemic could end within a short period after several countries have offered several treatments. The main problem is humanity's exposure to other epidemics similar to the COVID-19 epidemic in its work and its deadly impact on humanity and at that, we will have to wait for many years before obtaining the necessary drug For the treatment of those epidemics.

\section{COVID-19 Impact on Ensuring Quality Assurance, Accreditation and Certification of HEIs}

Implementing quality assurance in the light of the presence of COVID-19 appears to be a relatively controversial issue, as it seems difficult to apply all academic standards, whether when applying programmatic or institutional accreditation to the educational institution taking into account the restrictions and barriers for the educational institution. It is also difficult for the higher educational institution, if not to say impossible, to apply all the standards regulating quality taking into account the new conditions of the epidemic, its spread, and its impact, whether on the educational institution, on students, or even on graduates. Thus, the quality assurance bodies find themselves facing a major dilemma in ensuring the safety of the standards of the educational institution without the ability to make a site visit to the institution [42]. We know for sure that the accreditation process can be conducted remotely without the necessity or the need to carry out the site-visit, but this matter does not apply to all quality assurance institutions as some of them require the visit as a basic condition for the accreditation process. Quality Assurance bodies find themselves faced with two options: either to extend accreditation to universities whose accreditation is about to expire, and in this case, the extension can be for a year or even two years depending on the extent of the virus's spread, its impact, its ability to develop itself and the human ability to deal with it, or to implement the accreditation process completely remotely, with the requirement of a site-visit to the educational institution in the event of an improvement in the health situation. Quality assurance institutions can grant conditional accreditation as an acceptable option during this difficult period.

\section{Dark prospects and Bleak Future: Mutation of COVID-19 and the Emergence of Other Viruses}

Perhaps the most controversial posibility is the fear of new epidemics emerging in the coming years so that the current decade of the twenty-first century will be the decade of biological warfare between humanity on one side, and diseases on the other side. COVID-19 appears as the first example of this pessimistic 
state of humanity's ability to withstand the face of these wars and deal with them. The nightmare that we have to think about for the moment is the mutation of COVID-19 into a new virus different in its impact and effects from COVID-19. In this regard, it seems difficult to predict the future of mankind and the future of work, cultural, intellectual, and cognitive activities, in addition to the difficulties related to safety and security, and the possibilities available to preserve humanity's immunity and develop scientific studies to cope with the resulting difficulties. It also seems difficult for universities and higher education institutions to operate, bearing in mind the difficulties that could result from this pessimistic situation that causes frustration, anxiety, and fear. This also appears to be the case for quality assurance agencies. In this regard, quality assurance agencies must work to develop new, specific, and strict standards that ensure the safety of the educational process and that it meets the required standards. Humanity must prepare itself for any new virus, and doctors and scientists must prepare themselves for any event that may occur in the coming years.

\section{Suggestions and Recommendations}

1. Establishing Higher Education Emergency Response Network HEERN specialized in higher education at an international level related to providing recommendations and advice to universities and higher education institutions so that this network would have a direct role in taking the right and appropriate steps at the right time so that the losses resulting from the delay in decision-making are avoided.

2. International quality agencies are advised to provide a package of updates related to dealing with emergency management and dealing with ensuring the quality of education in universities by developing their educational standards and systems.

3. Quality assurance agencies are advised to prepare initial and temporary work plans to deal with university accreditation, either by extending the institutional accreditation of higher education institutions and suspending programmatic accreditation or by building a new system for programmatic accreditation that ensures that universities and higher education institutions apply all standards regulating accreditation.

4. Medical colleges in universities are advised tothink of conducting focused and intensive research on immunity, prevention, the structure of viruses, and the way they mutate and evolve.

5. Despite the difficult conditions that all countries of the world suffer from, governments must provide financial grants and pour money into universities for the purpose of conducting applied research on viruses and their mechanism. Regarding financing, we recommend that the International Monetary Fund IMF should provide financial grants to universities for the purpose of conducting studies and research focused on strengthening personal immunity.

6. Universities and higher education institutions should provide a flexible mechanism to teach their practical and theoretical curricula. In this regard, colleges can teach all theoretical programs through the distance education system. Regarding practical programs, HEIs can teach those programs following the in-person mode in the form of very small groups of 4-6 students taking the utmost safety and security and applying all prevention and triage protocols.

7. Universities must automate all educational institution resources, all documents, and supporting documents, keep backup copies of these documents and papers, and keep backup copies of these 
backup copies and save them in different places. These automated resources can contribute to facilitating the accreditation of an institution's educational programs.

8. Faculties of Technology and Informatics in universities must design specialized programs to connect students with teachers and to automatically save lectures either through special Google Drive links or by direct uploading to the university's specialized channels on the Internet or on YouTube.

9. Universities must focus on information security and protecting their databases in these difficult circumstances.

10. Universities should focus on behavioral psychology to facilitate and clarify the transition to the new teaching methodology and facilitate this task for students and university faculty and administrative staff.

11. Universities must upload all practical skills on the Internet and send special fixed links to students that can be accessed 24/7.

12. We recommend employers to deal with university graduates during the past year with transparency and without discrimination because the virus has affected everyone.

13. We recommend that international NGOs support international research centers for the purpose of studying the promotion of prevention and personal protection methods.

\section{CONCLUSION}

Humanity can stand up to this virus and overcome it, just as it has overcome previous viruses during the past decades, and we, as researchers and specialists in the higher education sector, must contribute to spreading and increasing awareness to provide the best practices that can contribute to protecting the higher education sector in these difficult days.

\section{REFERENCES}

1. 19 Pandemic Left 147 Million People Unemployed Globally: Study -COVID-19 HUB. (2020, July 12 Retrieved November 21, 2020, from https://covid19.tabipacademy.com/2020/07/13/covid-19-pandemicleft-147-million-people-unemployed-globally-study.

2. A third of the global population is on coronavirus lockdown -here's our constantly updated list of countries and restrictions. 2020. Retrieved November 21, 2020, from https://www.businessinsider.in/international/ news/a-third-of-the-global-population-is-on-coronavirus-lockdown-x2014-hereaposs-our-constantlyupdated-list-of-countries-and-restrictions/slidelist/75208623.cms.

3. Aristovnik, A., Keržič, D., Ravšelj, D., Tomaževič, N., \&amp; Umek, L. 2020. Impacts of the COVID-19 Pandemic on Life of Higher Education Students: A Global Perspective. https://doi.org/10.20944/ preprints202008.0246.v2.

4. Arora, A. 2020. Life after COVID-19: A better normal? Perspectives in Public Health, 175791392095159. https://doi.org/10.1177/1757913920951591.

5. Azoulay, U. 2020. 290 million students out of school due to COVID-19: UNESCO releases first global numbers and mobilizes response. Retrieved November 21, 2020, from https://en.unesco.org/news/290million-students-out-school-due-covid-19-unesco-releases-first-global-numbers-and-mobilizes. 
6. Big Tech is worth over $\$ 5$ trillion. (n.d.). Retrieved November 21,2020 , from https://www.bloomberg.com/ opinion/articles/2020-10-07/amazon-apple-google-facebook-face-5-trillion-reckoning-after-house-report.

7. Book fairs in the age of Covid-19. (n.d.). Retrieved November 21, 2020, from http://www.aldusnet.eu/khub/book-fairs-the-age-of-covid-19.

8. Buchholz, L., Fine, G. A., \& amp; Wohl, H. 2020. Art markets in crisis: How personal bonds and market subcultures mediate the effects of COVID-19. American Journal of Cultural Sociology, 8(3): 462-476.

9. Burns, J. 2020. Coronavirus: 13 UK universities 'could go bust without bailout'. Retrieved November 21, 2020, from https://www.bbc.com/news/uk-53280965.

10. Can we compare the COVID-19 and 2008 crises? 2020. Retrieved November 21, 2020, from https://www. atlanticcouncil.org/blogs/new-atlanticist/can-we-compare-the-covid-19-and-2008-crises.

11. Cases Soar in Italy, Iran and South Korea as Alarm Grows. 2020. Retrieved November 21, 2020, from http://www.nytimes.com/2020/02/27/world/coronavirus-news.html.

12. Chappell, B. 2020. Coronavirus: More New Cases Are Now Reported Outside China Than Inside. Retrieved November 21, 2020, from http:/www.npr.org/sections/goatsandsoda/2020/02/26/809568686/ coronavirus-more-new-cases-are-now-reported-outside-china-than-inside.

13. Coronavirus COVID-19 wipes $\$ 50$ billion off global exports in February alone, as IMF pledges support for vulnerable nations || UN News. (n.d.). Retrieved November 21, 2020, from https://news.un.org/en/ story/2020/03/1058601.

14. Coronavirus disease 2019 (COVID-19) Situation Report - 94.

15. Coronavirus Exposure, But No Symptoms. (n.d.). Retrieved November 21, 2020, from http://www. seattlechildrens.org/conditions/a-z/coronavirus-exposure-but-no-symptoms.

16. Coronavirus will cost global tourism at least $\$ 1.2$ trillion. 2020. Retrieved November 21, 2020, from https://unctad.org/news/coronavirus-will-cost-global-tourism-least-12-trillion.

17. Cunha, B. A. 2004. Influenza: Historical aspects of epidemics and pandemics. Infectious Disease Clinics of North America, 18(1): 141-155.

18. Dabo Guan Dabo, Guan Daoping Wang and Others, April 2020: Global economic footprint of the COVID-19 pandemic.

19. Donthu, N., \& amp; Gustafsson, A. 2020. Effects of COVID-19 on business and research. Journal of Business Research, 117: 284-289.

20. From SARS to 2019-Coronavirus (nCoV):U.S.-China Collaborations on Pandemic Response, Jennifer Bouey, 2020.

21. Huremović, D. 2019. Brief History of Pandemics (Pandemics Throughout History). Psychiatry of Pandemics, pp. 7-35. https://doi.org/10.1007/978-3-030-15346-5_2.

22. International Association of Universities -The Global Voice of Higher Education. (n.d.). Retrieved November 21, 2020, from http://www.iau-aiu.net/Covid-19-Higher-Education-challenges-and-responses. 
23. International students now worth $£ 25$ billion to UK economy - new research. (n.d.). Retrieved November 21, 2020, from https:/www.universitiesuk.ac.uk/news/Pages/International-students-now-worth-25-billionto-UK-economy---new-research.aspx.

24. Internet usage in rural India overtakes urban areas. (n.d.). Retrieved November 21, 2020, from https:// www.warc.com/newsandopinion/news/internet-usage-in-rural-india-overtakes-urban-areas/43588.

25. Jarus, O. 2020. 20 of the worst epidemics and pandemics in history. Retrieved November 21, 2020, from https://www.livescience.com/worst-epidemics-and-pandemics-in-history.html.

26. Khan, A.H., Sultana, M.S., Hossain, S., Hasan, M.T., Ahmed, H.U., \& amp; Sikder, M.T. 2020. The impact of COVID-19 pandemic on mental health \&amp; wellbeing among home-quarantined Bangladeshi students: A cross-sectional pilot study. Journal of Affective Disorders, 277: 121-128.

27. Korin Miller Updated March 10, \&amp; Miller, K. (n.d.). 6 of the Worst Pandemics in History. Retrieved November 21, 2020, from https:/www.health.com/condition/infectious-diseases/worst-pandemics-inhistory.

28. Lateef, O.A., Khamidi, M.F. \&amp; Idrus, A. 2011. Behavioural issues in maintenance of university buildings. Journal of Retail \&amp; Leisure Property, 9(5): 415-428.

29. Mahmoudinezhad, G., Moghimi, S., \&amp; Weinreb, R.N. 2020. COVID-19 Pandemic: Are We Back to Normal? Journal of Glaucoma, 29(8): 611-612.

30. Mailonline, R. 2020. Coronavirus: Pandemic costs world's economy \$3.8TRILLION. Retrieved November 21, 2020, from https://www.dailymail.co.uk/sciencetech/article-8506463/Covid-19-pandemic-cost-worldseconomy-3-8TRILLION.html.

31. Maintenance and operation costs model for university buildings. 2017. Tehnicki Vjesnik -Technical Gazette, 24 (Supplement 1). https://doi.org/10.17559/tv-20140606093626.

32. Mishra, L., Gupta, T. \&amp; Shree, A. 2020. Online teaching-learning in higher education during lockdown period of COVID-19 pandemic. International Journal of Educational Research Open, 100012. https:// doi.org/10.1016/j.ijedro.2020.100012.

33. Mukhopadhyay, A. (n.d.). The rise of online learning raises questions about the price we put on education. Retrieved November 21, 2020, from https:/qz.com/india/1852436/e-learning-amid-covid-19-raisesquestions-about-cost-of-education.

34. Ozili, P.K., \&amp; Arun, T. 2020. Spillover of COVID-19: Impact on the Global Economy. SSRN Electronic Journal. https://doi.org/10.2139/ssrn.3562570.

35. Plater, W., Tempel, G., \&amp; Shaker, G. 2020. Some colleges will be forced to close permanently as the coronavirus hits hard. Retrieved November 21, 2020, from https://www.marketwatch.com/story/somecolleges-will-be-forced-to-close-permanently-as-the-coronavirus-hits-hard-2020-03-12.

36. Price waterhouse Coopers. (n.d.). COVID-19: What it means for industrial manufacturing. Retrieved November 21, 2020, from https://www.pwc.com/us/en/library/covid-19/coronavirus-impacts-industrialmanufacturing.html. 
37. Public colleges face looming financial blow from state budget cuts. (n.d.). Retrieved November 21, 2020, from https://www.insidehighered.com/news/2020/04/13/public-colleges-face-looming-financialblow-state-budget-cuts.

38. Publishing, H. (n.d.). COVID-19 basics. Retrieved November 21, 2020, from http://www.health.harvard. edu/diseases-and-conditions/covid-19-basics.

39. Qiu, W., Rutherford, S., Mao, A., \&amp; Chu, C. 2017. The Pandemic and its Impacts. Health, Culture and Society, 9: 1-11.

40. Rapanta, C., Botturi, L., Goodyear, P., Guàrdia, L., \&amp; Koole, M. 2020. Online University Teaching During and After the Covid-19 Crisis: Refocusing Teacher Presence and Learning Activity. Postdigital Science and Education, 2(3): 923-945.

41. Roos, D. 2020. How 5 of History's Worst Pandemics Finally Ended. Retrieved November 21, 2020, from https://www.history.com/news/pandemics-end-plague-cholera-black-death-smallpox.

42. Site visits must be part of the accreditation process. (n.d.). Retrieved November 21, 2020, from https:// www.universityworldnews.com/post.php?story=20160927171548595.

43. Sydney University. 2020. Socio-economic, environmental impacts of COVID-19 quantified. Retrieved November 21, 2020, from http://www.sciencedaily.com/releases/2020/07/200709141538.htm.

44. The Changing New World Order After Covid-19. (n.d.). Retrieved November 21, 2020, from https://www. gencdiplomatlar.com/awareness/articles/the-changing-new-world-order-after-covid-19.html.

45. The impact of the coronavirus (COVID-19) crisis on development finance. 2020. Retrieved November 21, 2020, from http://www.oecd.org/coronavirus/policy-responses/the-impact-of-the-coronavirus-covid19-crisis-on-development-finance-9de00b3b.

46. Tognotti, E. 2009. Influenza pandemics: A historical retrospect. The Journal of Infection in Developing Countries, $\mathbf{3}(05)$.

47. Top 10 Pandemics in Human History. (2020, August 04). Retrieved November 21, 2020, from https:// www.humainpodcast.com/top-10-pandemics-in-human-history.

48. Universities’ $£ 2.5$ bn 'black hole’ will cost economy £6bn and 60,000 jobs, warns report. (n.d.). Retrieved November 21, 2020, from https:/www.ucu.org.uk/article/10759/Universities-2.5bn-black-hole-will-costeconomy-6bn-and-60000-jobs-warns-report.

49. Universities to lose thousands of jobs, hitting research. (n.d.). Retrieved November 21, 2020, from https:// www.universityworldnews.com/post.php?story=20200512133125853.

50. WHO announces COVID-19 outbreak a pandemic, Dr Tedros Adhanom Ghebreyesus, WHO's DirectorGeneral, that COVID-19 can be characterized as a pandemic: https:/www.euro.who.int/en/health-topics/ health-emergencies/coronavirus-covid-19/news/news/2020/3/who-announces-covid-19-outbreak-apandemic.

51. Winck, B. 2020. Coronavirus fallout has erased $\$ 3.5$ trillion in workforce income, UN agency says. Retrieved November 21, 2020, from http://www.businessinsider.com/coronavirus-impact-on-economytrillions-workforce-income-erased-ilo-study-2020-9. 
52. Worst Pandemics in Global History -What We Can Learn From Them? (2020, October 14). Retrieved November 21, 2020, from https://www.publichealthonline.org/worst-global-pandemics-in-history.

53. Wright, R., \&amp; Koch, N. 2009. Ivy League and Geography in the US. International Encyclopedia of Human Geography, pp. 616-621. https://doi.org/10.1016/b978-008044910-4.00323-0.

54. Written by Laila Kearney, W. (n.d.). Coronavirus: US oil has dropped to below $\$ 0$ dollars a barrel. Here's what it means. Retrieved November 21, 2020, from https://www.weforum.org/agenda/2020/04/oil-barrelprices-economic-supply-demand-coronavirus-covid19-united-states.

55. Yaya, S., Otu, A., \&amp; Labonté, R. 2020. Globalisation in the time of COVID-19: Repositioning Africa to meet the immediate and remote challenges. Globalization and Health, 16(1). 
